\title{
Habitat Selection and Activity Patterns of Japanese Serows and Sika Deer with Currently Sympatric Distributions
}

\author{
Yoshikazu Seki ${ }^{1,2, *}$ and Shin-ichi Hayama ${ }^{1}$ \\ 1 School of Veterinary Medicine, Nippon Veterinary and Life Science University, 1-7-1, Kyonancho, Musashino, \\ Tokyo 180-8602, Japan; hayama@nvlu.ac.jp \\ 2 Department of Agri-Environmental Sciences, Tamagawa University, 6-1-1, Tamagawagakuen, Machida, \\ Tokyo 194-8610, Japan \\ * Correspondence: yseki@agr.tamagawa.ac.jp
}

Citation: Seki, Y.; Hayama, S.-i. Habitat Selection and Activity Patterns of Japanese Serows and Sika Deer with Currently Sympatric Distributions. Animals 2021, 11, 3398. https://doi.org/10.3390/ani11123398

Academic Editor: Torsten Wronski

Received: 18 October 2021

Accepted: 26 November 2021

Published: 28 November 2021

Publisher's Note: MDPI stays neutral with regard to jurisdictional claims in published maps and institutional affiliations.

Copyright: (c) 2021 by the authors. Licensee MDPI, Basel, Switzerland. This article is an open access article distributed under the terms and conditions of the Creative Commons Attribution (CC BY) license (https:// creativecommons.org/licenses/by/ $4.0 /)$.
Simple Summary: Investigating the interspecific interactions between species provides a suitable model for understanding the mechanisms of coexistence between sympatric species. We assessed the spatial and temporal partitioning of spaces between Japanese serows (Capricornis crispus) and sika deer (Cervus nippon), which are usually allopatric, in an area with early-stage invasion of sika deer into Japanese serow habitat. The habitat selection and activity patterns of the two species were evaluated using camera traps. Both species were recorded in $>25 \%$ of the same camera sites and showed similar selection tendencies for water resources. The Japanese serows selected steep slopes, whereas the sika deer selected areas distant from human settlements, resulting in low spatial overlap. Additionally, the Japanese serows were more active during the daytime, whereas the sika deer were active at the crepuscule. The observed spatial and temporal partitioning likely reduces their encounter rates, thereby minimizing possible interference competition. However, spatial and temporal overlaps between the two species are likely to increase as the density of sika deer increases, potentially resulting in a decline in the density of Japanese serows with smaller body sizes. Trapping for deer management should be focused on areas with gentle slopes, away from valleys and human settlements, to reduce the unintentional capture of Japanese serows.

Abstract: The Japanese serow (Capricornis crispus) and sika deer (Cervus nippon) in Japan are usually allopatric. However, a recent expansion in the distribution range of sika deer, combined with an increase in abundance, has resulted in an overlap of the distribution ranges of the two species. We examined the habitat selection and activity patterns of Japanese serows and sika deer using camera traps placed at 83 sites within a $210 \mathrm{~km}^{2}$ study area, where the distribution range of these two species has recently overlapped. Although both species were photographed throughout the study area, we observed a low spatial overlap between them. The Japanese serows selected steep slopes, and the sika deer selected areas far away from human settlements. In addition, the Japanese serows and sika deer exhibited temporal partitioning with diurnal and crepuscular activity patterns, respectively. The observed partitioning could be explained by differences in their species-specific habitat selections, rather than competition, because the photographic capture rate of the Japanese serows was not affected by that of the sika deer and vice versa. These partitioning behaviors are likely to reduce the rate of encounters between the two ungulates, which enables their coexistence considering the sika deer density remains low.

Keywords: Capricornis crispus; Cervus nippon; activity level; camera trap; habitat use; interference competition; niche; overlap; spatial partitioning; temporal partitioning

\section{Introduction}

Interspecific interactions influence species abundance and community composition [1]. Predation exerts significant influence on the dynamics of prey populations and their communities [2-6]. To reduce predation risk, herbivores may change their foraging behavior 
and habitat use [7-10]. Interspecific competition also influences species abundance, habitat use, and diet [11-15]. Ecologically similar sympatric species elude or reduce competition by spatial and temporal partitioning of habitat, or by exploiting different food resources, which may promote coexistence [16-28]. Studies on interspecific interactions are crucial for understanding the mechanisms of coexistence between sympatric species.

The distribution ranges of various deer species have expanded in recent decades worldwide, with drastic increases in abundance [29], thereby prompting more studies on the interspecific interactions between deer and other species; the modification of vegetation due to increased deer foraging has been well-documented [29-31]. By modifying vegetation, deer indirectly affect the population and community composition of small animals utilizing the vegetation as food resources or resting and breeding sites [29,32-35]. An increase in browsing pressure by deer can also lead to significant declines in the population of some large mammals through interspecific competition. For example, abundant white-tailed deer (Odocoileus virgininianus) caused an indirect extirpation of the black bear (Ursus americanus) population on Anticosti Island by over-browsing berry-producing shrubs [5]. Studies on interspecific competition among sympatric deer and other species are essential to identify ways of preventing such significant declines in wildlife populations.

Two ungulates, the sika deer (Cerous nippon) and the Japanese serow (Capricornis crispus), are normally allopatric in Japan [36,37]. However, recent population growth and range expansion in sika deer have resulted in an overlap in the distribution ranges of these two ungulates. Comparatively little is known about interspecific competition between Japanese serows and sika deer in regions where they occur sympatrically. However, declines in the population of Japanese serows, with increasing sika deer populations, have been reported in some areas in Japan [36,38]. This may be a result of interspecific competition between these two species. Although two comparative studies on the food habits of Japanese serows and sika deer exhibited differences in feeding selection between the two species living in the same area $[39,40]$, their food habits were found to be similar in the area where the food supply was scarce due to heavy grazing by sika deer [41]. These results indicate that the extent of interspecific competition between the two ungulates could increase with the increasing population of sika deer.

However, even if there is a high dietary overlap between Japanese serows and sika deer in the same area, differences in their habitat use have been shown [42]. Takada et al. [43] also demonstrated that Japanese serows and sika deer have exhibited differences in their habitat use in terms of vegetation and topography. However, these two studies on habitat use were conducted at a relatively finer scale $\left(1-2 \mathrm{~km}^{2}\right)$ in areas where densities of sika deer are relatively high (10.4-15.0 individuals $\left./ \mathrm{km}^{2}\right)$. Since studies at different scales often yield a different numerical result or pattern [44], we also need to compare the habitat use between the two ungulates at a broader scale. In addition, in other areas with high sika deer densities (mean of 17.9 individuals $/ \mathrm{km}^{2}$ ), the Japanese serows selectively chose habitats to avoid sika deer [37]. Since the spatial partitioning may be a result of previous competitive interactions and competitive exclusion [45-47], the Japanese serows may have shifted or might shift their ecological niche in the future in areas with relatively higher densities of sika deer. To adequately assess the interspecific competition between Japanese serows and sika deer, comparisons should be also made in areas with low sika deer densities. In addition to habitat and feeding-related drivers, time is a critical dimension in ecology [48]. Temporal partitioning may lead to a reduced competition where interspecific competition might otherwise occur [21,49]. Although the activity pattern of sika deer have been well documented [50-54], a systematic survey on the activity pattern of Japanese serow populations is lacking; only one study has included an individual radio-collared Japanese serow [55]. Therefore, whether Japanese serows and sika deer exhibit temporal partitioning in sympatric areas remains unclear.

On an evolutionary timescale, to minimize the loss of fitness incurred through competition, natural selection would be expected to promote clear partitioning in resource use between regularly interacting sets of species. Thus, evidence for actual competition 
between members of an established community of large herbivores is generally difficult to obtain [47]. Therefore, simultaneous studies on habitat use and activity between Japanese serows and sika deer, at different stages of range expansion of the sika deer, provides a model to comprehend the mechanisms of coexistence, not only for the two species but also for other ungulate communities. The assessment of the interspecific competition between Japanese serows and sika deer is also essential for the conservation of Japanese serows, which are solitary and territorial animals that typically live in low densities [56,57]. Although the Japanese serow has been legally protected since 1955, the species is listed as a threatened local population in four regions of Japan [58]. However, recently, many individual Japanese serows have been unintentionally captured in snare traps set for the management of sika deer, and approximately $30 \%$ of these captured individuals sustained injuries in the process [59]. Additional knowledge about the habitat selection behavior in sympatric populations of these two ungulates can enable effective management of sika deer and reduce the unintentional capture of Japanese serows.

The purpose of this study was to compare the habitat selection and activity patterns of sympatric Japanese serows and sika deer, using camera traps in an area with an early-stage invasion of sika deer into the habitat occupied by populations of Japanese serows at the landscape scale, i.e., the third-order habitat selection process defined by Johnson [60]. Since Japanese serows and sika deer are usually allopatric [36,37], we hypothesized that the two species may exhibit spatial partitioning in areas where their distribution has recently overlapped. Even if ungulates overlapped spatially, differences in activity patterns may reduce the risk of encounters $[49,61]$. Therefore, we also hypothesized that Japanese serows and sika deer may exhibit temporal partitioning in the sympatric area.

\section{Materials and Methods}

\subsection{Study Area}

The study was conducted in Tsumagoi Village $\left(337.58 \mathrm{~km}^{2}\right)$, Gunma Prefecture, central Honshu, Japan, which is located in a cool temperate zone $\left(36^{\circ} 31.0^{\prime} \mathrm{N}, 138^{\circ} 31.49^{\prime} \mathrm{E}\right.$; 700-2550 m elevation; Figure 1). The study area is an important cabbage (Brassica oleracea var. capitata) growing area. Moreover, the tourism industry is important, and there are several leisure facilities, such as campgrounds, golf courses, cottage areas, hot-spring areas, and skiing areas. The vegetation of the study area is dominated by deciduous broadleaved trees and conifers. According to data collected from Tashiro Weather Station $(1230 \mathrm{~m})$, located in the southern part of Tsumagoi, between 1980 and 2010, the mean annual temperature was $7.1^{\circ} \mathrm{C}\left(-4.6^{\circ} \mathrm{C}\right.$ in January and $19.5^{\circ} \mathrm{C}$ in August $)$ and the mean annual precipitation was $1506 \mathrm{~mm}$. The ground was typically covered with snow from mid-December to mid-April.

The mean \pm standard deviation (SD) of the population density estimated by the block count method [62], which was conducted in four areas in October 2012, was $1.77 \pm 1.70-2.28 \pm 2.66$ for Japanese serows and $1.40 \pm 0.95 / \mathrm{km}^{2}$ for sika deer. The Gunma Prefecture regarded Tsumagoi as a low density area for sika deer $\left(<1.5\right.$ individuals $/ \mathrm{km}^{2}$ in 2012, computed from Gunma [63]). Thus, we considered that the deer density was low during the study period. In Tsumagoi, the presence of sika deer was not observed during the 1996 survey, but the 2008 survey first confirmed the sparse distribution of sika deer [64]. Additionally, there were no reports of crop damage by sika deer before 2008; however, such reports have gradually increased since 2013 [65]. Therefore, we considered that the sika deer range has recently expanded into the study area, possibly between 1996 and 2008 . In this area, almost no deer were observed by camera traps during the months between December and April in the period 2013-2015, possibly because they had migrated to other areas (Y Seki, unpublished data). 


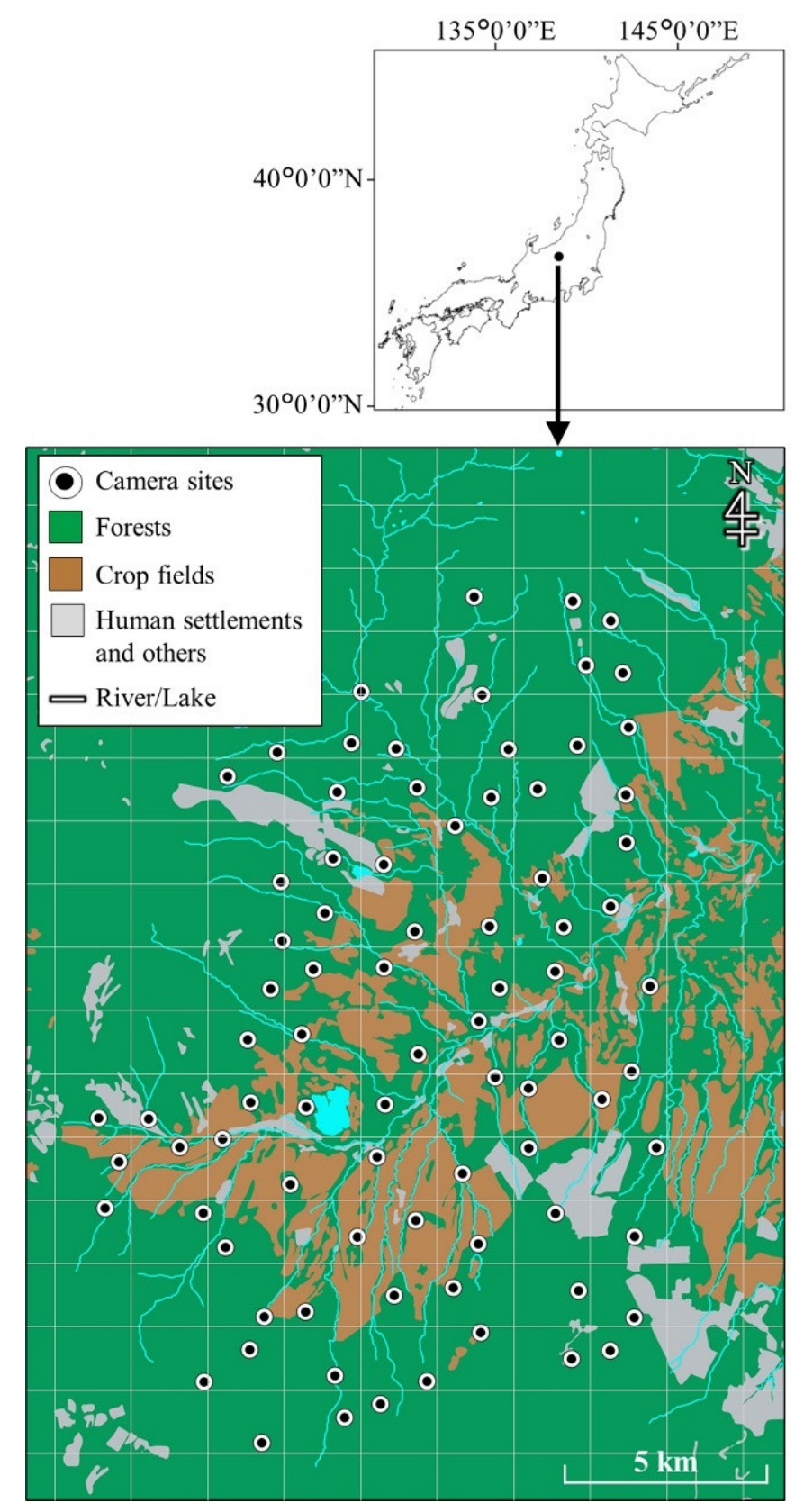

Figure 1. Study area in Tsumagoi, central Honshu, Japan. Camera traps were placed at 83 sites to monitor Japanese serows and sika deer between July and September 2012. The study area was divided into approximately $1.7 \times 1.7 \mathrm{~km}$ grids. The map was created based on national land use information (Ministry of Land, Infrastructure, Transport and Tourism of Japan) and 6-7th Japanese National Survey of the Natural Environment (Ministry of the Environment of Japan).

\subsection{Camera Trapping}

We divided the study area into approximately $1.7 \times 1.7 \mathrm{~km}$ grids obtained by equally dividing the Secondary Area Partition (approximately $10 \mathrm{~km}^{2}$ ) into 36 units. We used 20 camera traps (Ltl-Acorn 5210A, Zhuhai Ltl Acorn Electronics Co., Ltd., Guangdong, China) to investigate the activity and habitat use patterns of Japanese serows and sika deer. Between July and September 2012, we placed camera traps at a total of 83 sites (one camera inside each grid cell) in the study area, covering an area of approximately $210 \mathrm{~km}^{2}$ (866-2046 m elevation; Figure 1). The traps were moved to new locations approximately every two weeks. The mean \pm SD of the distance between two adjacent cameras was $1241 \pm 294 \mathrm{~m}$ (range of 856-2400 m). The circular size $\left(1.21 \mathrm{~km}^{2}\right)$, calculated from the mean 
distance between two adjacent cameras, was larger than the mean size of the annual home range of Japanese serows [56,57] and that of the summer home range of sika deer [66,67].

The traps were placed at a height of approximately $0.7-1.0 \mathrm{~m}$ above the ground, along animal trails, and were not baited. We set the delay period between consecutive events at $1 \mathrm{~min}$ and set three burst shots for each event.

\subsection{Environmental Variables}

We used geographic information system software (QGIS version 2.18.16, https:// www.npackd.org/p/qgis64/2.18.16, access date 26 November 2021) to evaluate the camera trap detection rates of the Japanese serows and sika deer. The vegetation maps used were at a scale of 1:25,000 and based on the 6-7th Japanese National Survey of the Natural Environment and base map information developed by the Geospatial Information Authority of Japan. Several environmental variables that may influence the habitat use of these two species were used [37,68-71], including land cover types (deciduous broadleaved forest, coniferous forest, grassland, and farmland), distributions of human land-use (human settlements and road) and water resources, and angle of terrain (hereafter referred to as slope). We obtained the areas of each land cover type and mean slope within buffers of $200 \mathrm{~m}$ radii around each camera site, along with distances to the nearest roads, human settlements, and water resources. The resulting buffer area size (12.6 ha) is close in value to the mean home range size of Japanese serows (12.7 ha, computed from Kishimoto and Kawamich [56] and Ochiai and Susaki [57]). We calculated the mean slope within each buffer using points generated every $20 \mathrm{~m}$ (1 point per $\left.400 \mathrm{~m}^{2}\right)$.

\subsection{Data Analysis}

To assess spatial overlap between Japanese serows and sika deer, we calculated Pianka's index ( $\alpha$; [72]), where $\alpha$ can range from 0 (no overlap) to 1 (complete overlap), using the photographic capture rates (the number of independent photographs per cameratrap day of sika deer or Japanese serows) at each site. Based on Yasuda [73], consecutive photographs of conspecifics were defined as independent when separated by more than $30 \mathrm{~min}$. Therefore, the same species photographed more than once by the same camera within 30 min was counted as a single event.

The effects of environmental variables on the occurrence of Japanese serows and sika deer at the capture sites were analyzed using a linear regression model. Because there were a large number of sites where the presence of Japanese serows and/or sika deer were not photographed, the following model was assumed to follow a zero-inflated Poisson (ZIP) distribution [74]:

$$
\begin{gathered}
\operatorname{ZIP}(y \mid q, \lambda)=\left\{\begin{array}{r}
\operatorname{Bernoulli}(0 \mid q)+\operatorname{Bernoulli}(1 \mid q) \times \text { Poisson }(y \mid \lambda) \text { if } y=0 \\
\text { Bernoulli }(1 \mid q) \times \text { Poisson }(y \mid \lambda) \text { if } y \geq 1
\end{array}\right. \\
\log (\lambda)=\beta_{0}+\beta_{1} z_{1}+\beta_{2} z_{2}+\beta_{3} z_{3}+\beta_{4} z_{4}+\beta_{5} z_{5}+\beta_{6} z_{6}+\beta_{7} z_{7}+\log T
\end{gathered}
$$

where $y$ is the number of independent photographs at each site, $q$ is the probability indicating the species presence at each site, $\lambda$ is the expected number of independent photographs, $\beta_{0}$ is a constant (intercept), $\beta_{1-7}$ are parameters, $z_{1-7}$ are covariates, and $T$ is each cameratrap day at each site. The covariates $\left(z_{1-7}\right)$ represent the mean slope $\left(^{\circ}\right)$, distance $(\mathrm{km})$ to the nearest road, distance to the nearest human settlements, distance to the nearest water resource, area $\left(\mathrm{km}^{2}\right)$ of deciduous broadleaved forest, area of coniferous forest, and photographic capture rate of the other study species, respectively.

We created separate models for each species (hereafter referred to as the serow and sika models). Grassland and farmland areas with a variance inflation factor (VIF) larger than 5 were excluded from the analyses to avoid multicollinearity. A VIF exceeding 5 suggests that the model is unstable and has a poor performance [75]. The VIF values of the other variables used in the analyses were $<3.73$. 
Prior to the analysis, all covariates were standardized to have a mean of 0 and a standard deviation of 1 . Non-informative priors were used for prior distribution of the parameters. Posterior distributions of all parameters were estimated using the Markov chain Monte Carlo (MCMC) method. Four chains were used for initialization, with 2000 iterations; the first 1000 of which were used for burn-in; the MCMC chains were unthinned. MCMC sampling was considered to be converged when the " $R$ hat" value was $<1.1$ [76].

To estimate activity patterns and activity levels (the proportion of time that animals spend active) of Japanese serows and sika deer, we fitted non-parametric circular kernel density models [77]. The median time between the first and last consecutive photographs of each species was considered the time of a capture event. We converted local time stamps of independent detections into radian units. We estimated their activity level with 10,000-times smoothed bootstrapping and carried out the randomization test and Wald test to detect differences in activity pattern and activity level between the two species. To determine interspecific overlaps in daily activity, we then estimated the coefficient of temporal overlap $\left(\Delta_{4}\right)$ ranging from 0 (no overlap) to 1 (complete overlap) [78]. We generated 10,000 times smoothed bootstrapping to assess the reliability of the $\Delta_{4}$ estimator and to estimate a 95\% confidence interval. Statistical significances in interspecific differences of daily activity patterns were assessed using Watson's two-sample test [79].

We defined spatial $(\alpha)$ and temporal $\left(\Delta_{4}\right)$ overlap indices with $\leq 50$ th percentile as "low", between 50th $<$ and $\leq 75$ th percentiles as "moderate", and $>75$ th percentile as "high" following previous studies [80-82]. All statistical analyses were performed in R (v4.0.2; [83]) using "car" package $[84,85]$ for the VIF analysis, the "rstan" package $[86,87]$ for estimation of the posteriors, the Stan code from the "brms" package $[88,89]$ to construct the serow and sika models, the "activity" package $[77,90]$ to estimate activity patterns and activity levels of Japanese serows and sika deer, and the "overlap" [91] and the "CircStats" packages [92] to estimate $\Delta_{4}$ and to assess its significance.

\section{Results}

The cumulative trapping effort over the study period was 1245 camera days. The total number of independent photographs was 96 for the Japanese serows and 88 for the sika deer. Out of 83 camera sites, Japanese serows were photographed at 46 sites and sika deer at 35 sites. The mean \pm SD of photographic capture rate (at sites with recorded presence) for each species was $2.09 \pm 1.13$ for the Japanese serows and $2.51 \pm 2.97$ for the sika deer. The number of camera sites at which both species, only one species, and neither species were photographed was 21, 39 (25 for the Japanese serows and 14 for the sika deer), and 23 sites, respectively. Both species were photographed throughout the study area (Figure 2). However, we observed low spatial overlap $(\alpha=0.34)$ between the two species.

The photographic capture rate of the Japanese serows was significantly positively correlated with the mean slope, and significantly negatively correlated with the distance to the nearest water resource (Figure 3), indicating that this species selected steep slopes and areas close to water resources. The photographic capture rate of the sika deer was significantly positively correlated with the distance to the nearest human settlements, and significantly negatively correlated with the distance to water resources (Figure 3), indicating that this species also selected areas close to water resources, and that they avoided areas close to human settlements. Habitat selection within each species was not affected by the photographic capture rates of the other study species (Figure 3).

Circular kernel density models indicated that the Japanese serows were more active during the daytime, whereas the sika deer were active at the crepuscule (Figure 4). Their activity patterns were significantly different $(p<0.001)$. We also observed significant temporal partitioning between the two species (mean $\Delta_{4}=0.692 ; 95 \%$ confidence interval, 0.565-0.783; $p<0.001$; Figure 5). The activity levels (the ratio of the areas under and above the curve of the circular probability density function in Figure 4) estimated for the Japanese serows and sika deer were 0.501 (95\% confidence interval, 0.349-0.585) and 0.530 
$(0.355-0.604)$, respectively, and there was no significant difference $(\mathrm{W}=0.105 \pm 0.087$, $p=0.745)$.

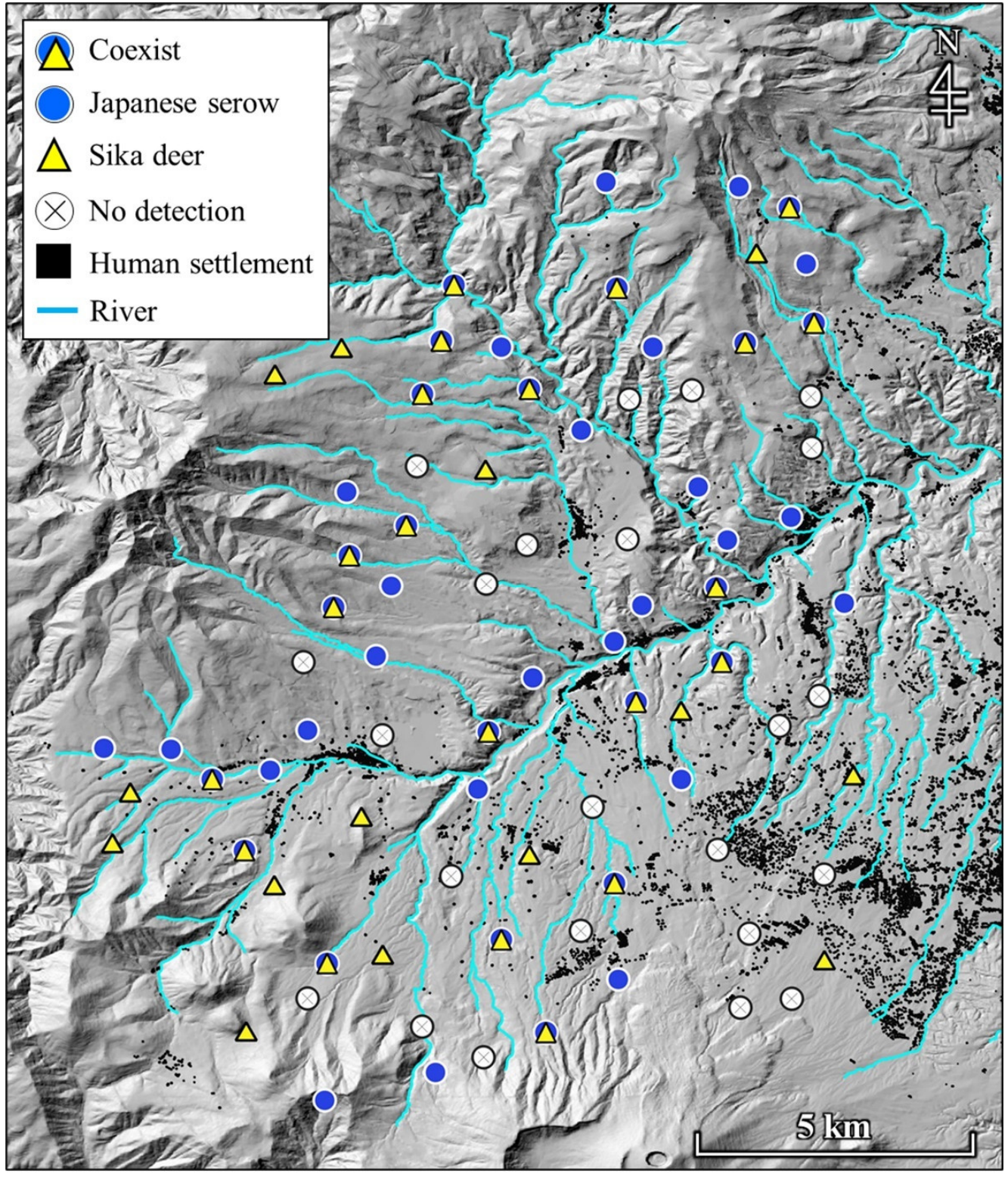

Figure 2. Distribution of Japanese serows and sika deer in Tsumagoi, central Honshu, Japan. Circles and triangles in the figure represent the sites where either Japanese serows or sika deer were photographed by camera traps, respectively. The map was created based on national land and base map information from the Ministry of Land, Infrastructure, Transport and Tourism of Japan. 


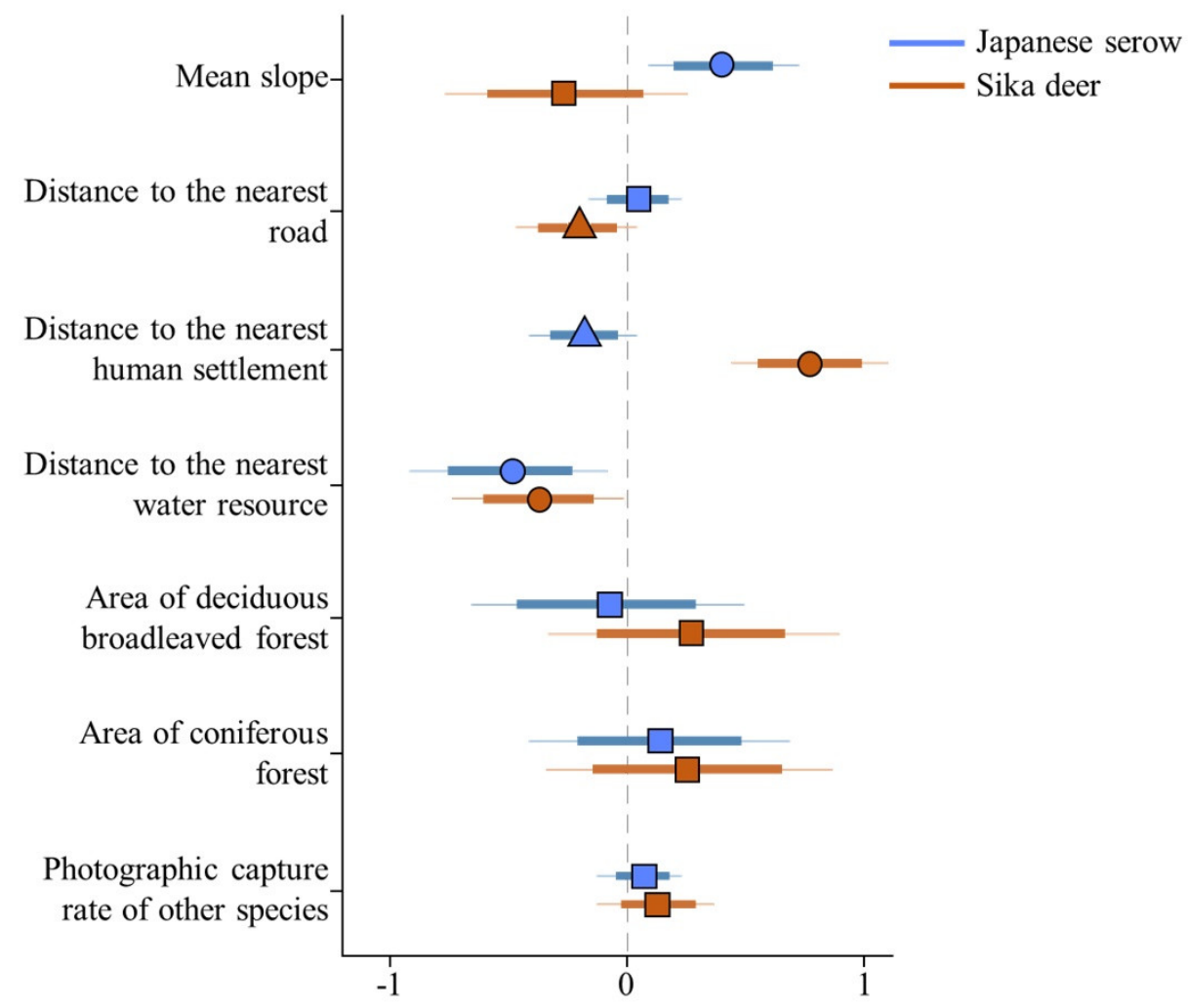

Figure 3. Posterior distribution of the parameters included in the occurrence model of Japanese serows and sika deer in Tsumagoi, central Honshu, Japan. Thin and thick lines represent the 95 and $80 \%$ credible intervals (CIs), respectively. Circles, triangles, and squares represent 95,80 and $<80 \% \mathrm{CI}$, respectively. Mean slope refers to the mean angle of terrain, and "other species" refers to the other (of the two) study species.

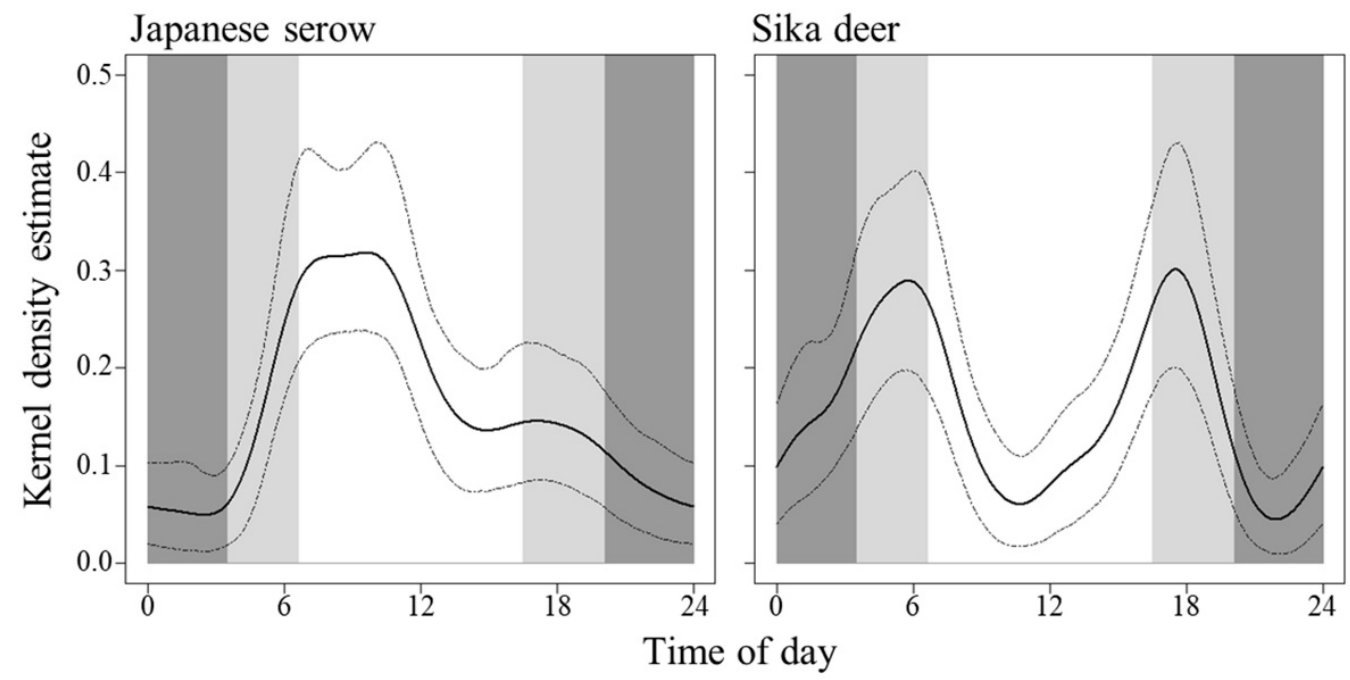

Figure 4. Circular kernel density models showing the overall daily activity patterns of Japanese serow and sika deer in Tsumagoi, central Honshu, Japan. Dashed lines indicate the $95 \%$ confidence intervals. The dark gray-shaded, light gray-shaded, and white areas indicate nighttime, dawn and dusk, and daytime, respectively. The day division was according to Ikeda et al. [52]: dawn (1 h before and after sunrise), dusk ( $1 \mathrm{~h}$ before and after sunset), daytime (from $1 \mathrm{~h}$ after sunrise to $1 \mathrm{~h}$ before sunset), and nighttime (from $1 \mathrm{~h}$ after sunset to $1 \mathrm{~h}$ before sunrise). Data on the time of sunrise and sunset in Maebashi $\left(36^{\circ} 23^{\prime} \mathrm{N}, 139^{\circ} 4^{\prime} \mathrm{E}\right)$, recorded by the National Astronomical Observatory of Japan, were used. 


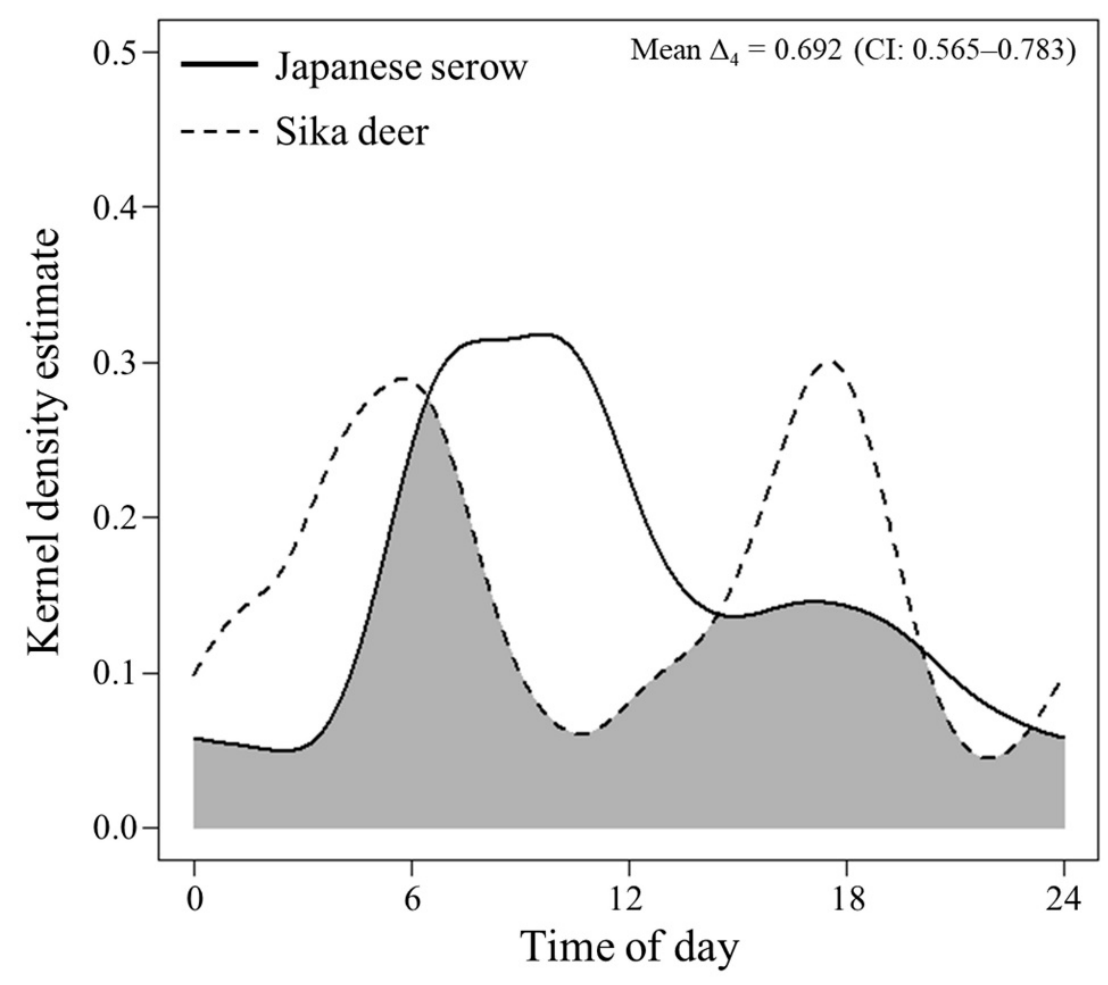

Figure 5. Comparison of daily activity patterns of Japanese serows and sika deer in Tsumagoi, central Honshu, Japan. The grey-shaded area indicates the mean coefficient of overlap, $\Delta_{4}$, between both species.

\section{Discussion}

Our results show that the two species exhibited temporal partitioning in their activity patterns, with the Japanese serows and sika deer demonstrating diurnal and crepuscular activity patterns, respectively (Figures 4 and 5). The activity pattern in the sika deer observed in our study is consistent with previous reports of the species in other areas $[50,52,53,93-96]$. Although several studies described lower nighttime activity in other populations $[50,52,53,94,96]$, a greater shift toward nocturnality has been apparent in areas with intense human activities $[51,54,94,95]$. Therefore, the low activity of the sika deer during the daytime probably resulted from the avoidance of humans $[52,54,97]$. Although little is known concerning the activity patterns of Japanese serows, the observed activity patterns of the Japanese serows were also consistent with a previous report that a radio-collared female was more active during the daytime than nighttime [55]. The Japanese serow has been legally protected since 1955, which might contribute to their diurnal activity. Despite this, and in contrast to the relatively well-known ecology of sika deer, there is a gap in the literature regarding the factors influencing the activity patterns of serow species. The few studies detailing the known activity patterns of other serow species of the genus Capricornis reported rather drastic differences. For example, mainland serows (C. sumatraensis) were observed to be more active at night [98], red serows (C. rubidus) from the afternoon through to midnight [99], Chinese serows (C. milneedwardsii) at dawn and dusk [61], and Himalayan serows (C. thar) more frequently in the morning and night [100]. Chen et al. [99] revealed that the time at which Chinese serows were more active changed from afternoon and midnight in the dry season to between sunrise and noon in the wet season, likely to avoid interference competition with red serows.

The Japanese serows and sika deer were recorded at more than $25 \%$ of the same camera sites (Figure 2), but spatial overlap indices between them were low. In addition, although the two species exhibited similar positive selections for habitats close to water resources, the Japanese serows prioritized steep slopes, whereas the sika deer showed a significant avoidance of human settlements (Figure 3). Because neither species' habitat 
selection was significantly affected by the photographic capture rate of the other (Figure 3), the observed results could be explained by species-specific requirements rather than by interspecific competition. Our observations that Japanese serows select steep slopes are corroborated by reports describing this habitat selection in other areas where sika deer density was low $\left(<1\right.$ individual $\left./ \mathrm{km}^{2}\right)$ [101], and where sika deer density was generally high $[37,42,43,102,103]$. The results indicate that Japanese serows do not select steep slopes to avoid sika deer. In fact, ungulate species with shorter limbs (such as Japanese serows) are specialized for climbing and navigating mountainous habitats, whereas those with longer limbs (such as sika deer) are specialized for speed, to run away from predators in open habitats $[104,105]$. Moreover, the utilization of steep-sloping terrain such as cliffs is a fundamental predator avoidance strategy in caprids [106]. In a study investigating this specific aspect of Japanese serow behavior, Takada et al. [107] suggested that their selection for steep and low-visibility habitats can be attributed to security. Thus, predator avoidance mechanisms could be a major factor influencing the difference in the observed selection for steep slopes between the Japanese serows and sika deer.

In contrast to Japanese serows, the most significant factor determining sika deer occurrence was (a disinclined) proximity to human settlements (Figure 3). Human disturbance likely influences the behavior, habitat use, and activity patterns of sika deer $[52,54,97,108-111]$. As deer species are extremely sensitive to human disturbance [47], the negative selection for human proximity may be a consequence of spatial human avoidance of sika deer. However, Japanese serows appear less sensitive to human presence, as the recorded abundance of Japanese serows tended to be high in areas close to human settlements (Figure 3). The difference between the sika deer and Japanese serows regarding the avoidance of human settlements could be a consequence of the difference in hunting pressure of each species; specifically, the sika deer is a game species, whereas the Japanese serow is a legally protected species.

We observed that the Japanese serows and sika deer selected areas close to water resources (Figure 3). Similarly, Ishida et al. [101] revealed that both these ungulate species were typically observed around valley-like terrain. Water is a critical resource for Cervidae and Bovidae in arid regions [112-115]. Although the climate in Japan is humid, the drinking water behaviors of the Japanese serows and sika deer observed in several areas [116-118] suggest that water is an important factor determining the behavior of these ungulates. To adequately assess the importance of water resources for Japanese serows and sika deer, systematic surveys for water use by these ungulates need to be conducted.

Japanese serows are smaller than sika deer (29.0-56.5 $\mathrm{kg}$ [119] versus $37.6-100.0 \mathrm{~kg}$ [120]), and larger species are typically superior to smaller ones [46]. Indeed, Japanese serows tend to avoid sika deer when they encounter each other, whereas sika deer likely ignore the presence of Japanese serows [121]. Although the Japanese serows and sika deer exhibited similar positive selection for water resources (Figure 3), the temporal partitioning observed between the two species reduced their encounter rates, minimizing possible interference competition between them. Similar partitioning mechanisms are known to occur not only within other sympatric herbivore communities $[49,61,99,100,122]$ but also within sympatric carnivore communities [21,123]. However, Koganezawa [36] revealed that population densities of Japanese serows decreased in areas where sika deer density exceeded 25 individuals $/ \mathrm{km}^{2}$; however, their densities were not significantly different in an area where sika deer density was $<10$ individuals $/ \mathrm{km}^{2}$. As the population density of sika deer increases, the encounter rate between the two species is also expected to increase, due to a moderate temporal overlap between them (Figure 5), which may influence the population levels of Japanese serows.

Although snare traps have been widely used for sika deer management, Japanese serows have typically been unintentionally captured, and many individuals have been injured in the process, sometimes fatally [59,124]. Our study sheds light on possible measures that can be adopted to minimize the risks of these accidents. The Japanese serows and sika deer selected areas close to water resources (Figure 3). The Japanese serows also 
selected steep slopes, whereas sika deer did not show any preference for slopes (Figure 3). In addition, both ungulates exhibited opposing tendencies with regard to the proximity of human settlements, with the Japanese serows tending to select areas close to human settlements, whereas sika deer selected areas far from human settlements (Figure 3). While trapping near human settlements reduces trapping effort from an accessibility perspective, this may increase the unintentional capture of Japanese serows. Thus, to reduce the unintentional capture of Japanese serows, sika deer trapping efforts near valleys should be minimized and instead focused on areas with gentler slopes away from human settlements.

\section{Conclusions}

The results of this study support our hypotheses that Japanese serows and sika deer exhibit spatial as well as temporal partitioning. This partitioning likely reduces the encounter rates between the two species, minimizing possible interference competition between them. However, spatial and temporal overlaps between Japanese serows and sika deer are likely to increase with the increase in sika deer density, which may result in a decline in the population density or a niche shift of Japanese serows with smaller body size. To better understand the factors influencing declines in the population of Japanese serows, more research needs to be conducted in areas with varied sika deer densities. Our study also identifies the following possible avenues to reduce the unintentional capture of the threatened Japanese serow in trapping efforts aimed at sika deer: trapping should be focused on areas with gentler slopes, away from valleys and human settlements.

Author Contributions: All authors contributed to the study conception and design. Y.S. collected the data and performed statistical analyses. The first draft of the manuscript was written by Y.S. and S.-i.H. commented on previous versions of the manuscript. All authors have read and agreed to the published version of the manuscript.

Funding: English editing was partly supported by a Grant-in-Aid for Scientific Research (C) (JSPS KAKENHI Grant Number 21K05673).

Institutional Review Board Statement: Ethical review and approval were waived for this study because the authors only set up camera traps and the study did not include any experiments with animals.

Data Availability Statement: The data presented in this study are available from the corresponding author on reasonable request.

Acknowledgments: We are grateful to the Wildlife Damage Control Support Center of Gunma Prefecture, Gunma Prefectural Institute of Agriculture and Forestry, and the Tsumagoi Village Office for their assistance during the survey.

Conflicts of Interest: The authors declare no competing interests.

\section{References}

1. Morin, P.J. Community Ecology; Blackwell Science: Oxford, UK, 1999; pp. 3-231.

2. Sinclair, A.R.E.; Norton-Griffiths, M. Does competition or facilitation regulate migrant ungulate populations in the Serengeti? A test of hypotheses. Oecologia 1982, 53, 364-369. [CrossRef] [PubMed]

3. Angelstam, P.; Lindström, E.; Widén, P. Synchronous short-term population fluctuations of some birds and mammals in Fennoscandia-Occurrence and distribution. Ecography 1985, 8, 285-298. [CrossRef]

4. Bergerud, A.T. Caribou, wolves and man. Trends Ecol. Evol. 1988, 3, 68-72. [CrossRef]

5. Lindstrom, E.R.; Andren, H.; Angelstam, P.; Cederlund, G.; Hornfeldt, B.; Jaderberg, L.; Lemnell, P.A.; Martinsson, B.; Skold, K.; Swenson, J.E. Disease reveals the predators: Sarcoptic mange, red fox predation, and prey populations. Ecology 1994, 75, 1042-1049. [CrossRef]

6. Melis, C.; Nilsen, E.B.; Panzacchi, M.; Linnell, J.D.C.; Odden, J. Roe deer face competing risks between predators along a gradient in abundance. Ecosphere 2013, 4, 1-12. [CrossRef]

7. Schmitz, O.J.; Beckerman, A.P.; O’Brien, K.M. Behaviorally mediated trophic cascades: Effects of predation risk on food web interactions. Ecology 1997, 78, 1388-1399. [CrossRef]

8. Ripple, W.J.; Larsen, E.J.; Renkin, R.A.; Smith, D.W. Trophic cascades among wolves, elk and aspen on Yellowstone National Park's northern range. Biol. Conserv. 2001, 102, 227-234. [CrossRef] 
9. Valeix, M.; Loveridge, A.J.; Chamaillé-Jammes, S.; Davidson, Z.; Murindagomo, F.; Fritz, H.; Macdonald, D.W. Behavioral adjustments of African herbivores to predation risk by lions: Spatiotemporal variations influence habitat use. Ecology 2009, 90, 23-30. [CrossRef] [PubMed]

10. Thaker, M.; Vanak, A.T.; Owen, C.R.; Ogden, M.B.; Niemann, S.M.; Slotow, R. Minimizing predation risk in a landscape of multiple predators: Effects on the spatial distribution of African ungulates. Ecology 2011, 92, 398-407. [CrossRef] [PubMed]

11. Chappell, M.A. Behavioral factors in the altitudinal zonation of chipmunk (Eutamias). Ecology 1978, 59, 565-579. [CrossRef]

12. Hairston, N.G. The experimental test of an analysis of field distributions: Competition in terrestrial salamanders. Ecology 1980, 61, 817-826. [CrossRef]

13. Karban, R. Community organization of Erigeron glaucus folivores: Effects of competition, predation, and host plant. Ecology 1989, 70, 1028-1039. [CrossRef]

14. Côté, S.D. Extirpation of a large black bear population by introduced white-tailed deer. Conserv. Biol. 2005, 19, 1668-1671. [CrossRef]

15. Ripple, W.J.; Beschta, R.L.; Fortin, J.K.; Robbins, C.T. Trophic cascades from wolves to grizzly bears in Yellowstone. J. Anim. Ecol. 2014, 83, 223-233. [CrossRef]

16. Jędrzejewski, W.; Jędrzejewska, B.; Szymura, A. Food niche overlaps in a winter community of predators in the Białowieża Primeval Forest, Poland. Acta Theriol. (Warsz) 1989, 34, 487-496. [CrossRef]

17. Namgail, T.; Fox, J.L.; Bhatnagar, Y.V. Habitat segregation between sympatric Tibetan argali Ovis ammon hodgsoni and blue sheep Pseudois nayaur in the Indian Trans-Himalaya. J. Zool. 2004, 262, 57-63. [CrossRef]

18. Whittaker, D.G.; Lindzey, F.G. Habitat use patterns of sympatric deer species on Rocky Mountain Arsenal, Colorado. Wildl. Soc. Bull. 2004, 32, 1114-1123. [CrossRef]

19. Rivero, K.; Rumiz, D.I.; Taber, A.B. Differential habitat use by two sympatric brocket deer species (Mazama americana and M. gouazoubira) in a seasonal Chiquitano forest of Bolivia. Mammalia 2005, 69, 169-183. [CrossRef]

20. Cromsigt, J.P.; Olff, H. Resource partitioning among savanna grazers mediated by local heterogeneity: An experimental approach. Ecology 2006, 87, 1532-1541. [CrossRef]

21. Hayward, M.W.; Slotow, R. Temporal partitioning of activity in large african carnivores: Tests of multiple hypotheses. Afr. J. Wildl. Res. 2009, 39, 109-125. [CrossRef]

22. Chillo, V.; Rodríguez, D.; Ojeda, R.A. Niche partitioning and coexistence between two mammalian herbivores in the Dry Chaco of Argentina. Acta Oecol. 2010, 36, 611-616. [CrossRef]

23. Darmon, G.; Calenge, C.; Loison, A.; Jullien, J.M.; Maillard, D.; Lopez, J.F. Spatial distribution and habitat selection in coexisting species of mountain ungulates. Ecography 2012, 35, 44-53. [CrossRef]

24. Schuette, P.; Wagner, A.P.; Wagner, M.E.; Creel, S. Occupancy patterns and niche partitioning within a diverse carnivore community exposed to anthropogenic pressures. Biol. Conserv. 2013, 158, 301-312. [CrossRef]

25. Pokharel, K.P.; Ludwig, T.; Storch, I. Spatial niche partitioning in sub-tropical solitary ungulates: Four-horned antelope and barking deer in Nepal. PLoS ONE 2015, 10, e0117917. [CrossRef]

26. Bianchi, R.D.C.; Olifiers, N.; Gompper, M.E.; Mourão, G. Niche partitioning among mesocarnivores in a Brazilian wetland. PLoS ONE 2016, 11, e0162893. [CrossRef] [PubMed]

27. De Satgé, J.; Teichman, K.; Cristescu, B. Competition and coexistence in a small carnivore guild. Oecologia 2017, 184, 873-884 [CrossRef]

28. Marrotte, R.R.; Bowman, J.; Morin, S.J. Spatial segregation and habitat partitioning of bobcat and Canada lynx. Facets 2020, 5, 503-522. [CrossRef]

29. Côté, S.D.; Rooney, T.P.; Tremblay, J.P.; Dussault, C.; Waller, D.M. Ecological impacts of deer overabundance. Annu. Rev. Ecol. Evol. Syst. 2004, 35, 113-147. [CrossRef]

30. Russell, F.L.; Zippin, D.B.; Fowler, N.L. Effects of white-tailed deer (Odocoileus virginianus) on plants, plant populations and communities: A review. Am. Midl. Nat. 2001, 146, 1-26. [CrossRef]

31. Takatsuki, S. Effects of sika deer on vegetation in Japan: A review. Biol. Conserv. 2009, 142, 1922-1929. [CrossRef]

32. Flowerdew, J.R.; Ellwood, S.A. Impacts of woodland deer on small mammal ecology. Forestry 2001, 74, 277-287. [CrossRef]

33. Stewart, A.J.A. The impact of deer on lowland woodland invertebrates: A review of the evidence and priorities for future research. Forestry 2001, 74, 259-270. [CrossRef]

34. Rooney, T.P.; Waller, D.M. Direct and indirect effects of white-tailed deer in forest ecosystems. For. Ecol. Manag. 2003, 181, 165-176. [CrossRef]

35. Gill, R.M.A.; Fuller, R.J. The effects of deer browsing on woodland structure and songbirds in lowland Britain. IBIS 2007, 149, 119-127. [CrossRef]

36. Koganezawa, M. Changes in the population dynamics of Japanese serow and sika deer as a result of competitive interactions in the Ashio Mountains, central Japan. Biosph. Conserv. 1999, 2, 35-44. [CrossRef]

37. Nowicki, P.; Koganezawa, M. Densities and habitat selection of the sika deer and the Japanese serow in Nikko National Park, central Japan, as rebealed by aerial censuses and GIS analysis. Biosph. Conserv. 2001, 3, 71-87. [CrossRef]

38. Hashimoto, Y.; Mori, Y. Transition in the distribution of the Japanese serow in the Suzuka Mountains Japanese Serow Protection Area. Wildl. Hum. Soc. 2018, 5, 1-8. [CrossRef] 
39. Kobayashi, K.; Takatsuki, S. A comparison of food habits of two sympatric ruminants of Mt. Yatsugatake, central Japan: Sika deer and Japanese serow. Acta Theriol. (Warsz) 2012, 57, 343-349. [CrossRef]

40. Endo, Y.; Takada, H.; Takatsuki, S. Comparison of the food habits of the sika deer (Cervus nippon), the Japanese serow (Capricornis crispus), and the wild boar (Sus scrofa), sympatric herbivorous mammals from Mt. Asama, central Japan. Mammal Study 2017, 42, 131-140. [CrossRef]

41. Asakura, G.; Kaneshiro, Y.; Takatsuki, S. A comparison of the fecal compositions of sympatric populations of sika deer and Japanese serows on Mt. Sanrei in Shikoku, Southwestern Japan. Mammal Study 2014, 39, 129-132. [CrossRef]

42. Yamashiro, A.; Kaneshiro, Y.; Kawaguchi, Y.; Yamashiro, T. Dietary overlap but spatial gap between sympatric Japanese serow (Capricornis crispus) and sika deer (Cervus nippon) on Eastern Shikoku, Japan. Mammal Study 2019, 44, 261-267. [CrossRef]

43. Takada, H.; Ohuchi, R.; Watanabe, H.; Yano, R.; Miyaoka, R.; Nakagawa, T.; Zenno, Y.; Minami, M. Habitat use and the coexistence of the sika deer and the Japanese serow, sympatric ungulates from Mt. Asama, central Japan. Mammalia 2020, 84, 503-511. [CrossRef]

44. Turner, M.G.; Gardner, R.H.; O'Neill, R.V. Landscape Ecology in Theory and Practice: Pattern and Process; Springer: New York, NY, USA, 2001; pp. 25-45.

45. DeBach, P. The competitive displacement and coexistence principles. Annu. Rev. Entomol. 1966, 11, 183-212. [CrossRef]

46. Schoener, T.W. Field experiments on interspecific competition. Am. Nat. 1983, 122, 240-285. [CrossRef]

47. Putman, R.J. Competition and Resource Partitioning in Temperate Ungulate Assemblies; Chapman \& Hall, London: London, UK, 1996; pp. 1-10.

48. Schoener, T.W. Resource partitioning in ecological communities. Science 1974, 185, 27-39. [CrossRef]

49. Ferreguetti, Á.C.; Tomás, W.M.; Bergallo, H.G. Density, occupancy, and activity pattern of two sympatric deer (Mazama) in the Atlantic Forest, Brazil. J. Mammal. 2015, 96, 1245-1254. [CrossRef]

50. Ando, C. The relationship between deer-train collisions and daily activity of the sika deer, Cerous nippon. Mammal Study 2003, 28, 135-143. [CrossRef]

51. Ikeda, T.; Takahashi, H.; Igota, H.; Matsuura, Y.; Azumaya, M.; Yoshida, T.; Kaji, K. Effects of culling intensity on diel and seasonal activity patterns of sika deer (Cervus nippon). Sci. Rep. 2019, 9, 17205. [CrossRef]

52. Ikeda, T.; Takahashi, H.; Yoshida, T.; Igota, H.; Matsuura, Y.; Takeshita, K.; Kaji, K. Seasonal variation of activity pattern in sika deer (Cervus nippon) as assessed by camera trap survey. Mammal Study 2015, 40, 199-205. [CrossRef]

53. Ikeda, T.; Uchida, K.; Matsuura, Y.; Takahashi, H.; Yoshida, T.; Kaji, K.; Koizumi, I. Seasonal and diel activity patterns of eight sympatric mammals in northern Japan revealed by an intensive camera-trap survey. PLoS ONE 2016, 11, e0163602. [CrossRef]

54. Van Doormaal, N.; Ohashi, H.; Koike, S.; Kaji, K. Influence of human activities on the activity patterns of Japanese sika deer (Cervus nippon) and wild boar (Sus scrofa) in Central Japan. Eur. J. Wildl. Res. 2015, 61, 517-527. [CrossRef]

55. Kishimoto, R. Early mother and kid behavior of a typical "follower", Japanese serow Capricornis crispus. Mammalia 1989, 53, 165-176. [CrossRef]

56. Kishimoto, R.; Kawamichi, T. Territoriality and monogamous pairs in a solitary ungulate, the Japanese serow, Capricornis crispus. Anim. Behav. 1996, 52, 673-682. [CrossRef]

57. Ochiai, K.; Susaki, K. Effects of territoriality on population density in the Japanese serow (Capricornis crispus). J. Mammal. 2002, 83, 964-972. [CrossRef]

58. Ministry of the Environment of the Government of Japan. The Japanese Red List. 2020. Available online: http://www.env.go.jp/ press /107905.html (accessed on 23 September 2021). (In Japanese)

59. Minami, M.; Takeshita, T.; Chikakiyo, H.; Suda, C.; Inoue, T.; Kishimoto, R. The influence of mistake capture by snare traps on the Japanese serow. Annu. Rep. Pro Nat. Found. Jpn. 2020, 29, 103-117, (In Japanese with English abstract).

60. Johnson, D.H. The comparison of usage and availability measurements for evaluating resource preference. Ecology 1980, 61, 65-71. [CrossRef]

61. Li, X.; Bleisch, W.V.; Jiang, X. Unveiling a wildlife haven: Occupancy and activity patterns of mammals at a Tibetan sacred mountain. Eur. J. Wildl. Res. 2018, 64, 53. [CrossRef]

62. Maruyama, N.; Nakama, S. Block count method for estimating serow populations. Jpn. J. Ecol. 1983, 33, $243-251$.

63. Gunma Conservation and Management of the Japanese Serow of 2016 in Gunma Prefecture. Available online: https://www.pref. gunma.jp/contents/000366682.pdf (accessed on 10 February 2021). (In Japanese).

64. Sakaniwa, H.; Anezaki, T. Change in the spatial distribution of sika deer (Cerous nippon) in Gunma Prefecture. Bull. Gunma Mus. Nat. Hist. (In Japanese). 2010, 14, 133-140.

65. Gunma Conservation and Management of the Sika Deer of 2020 in Gunma Prefecture. Available online: https://www.pref. gunma.jp/contents/100104428.pdf (accessed on 10 February 2021). (In Japanese).

66. Maeji, I.; Kurosaki, T.; Yokoyama, S.; Shibata, E. Home range of sika deer (Cervus nippon) on Mt. Ohdaigahara, central Japan. Nagoya Univ. For. Sci. 2000, 19, 1-10, (In Japanese with English abstract).

67. Takii, A.; Izumiyama, S.; Mochizuki, T.; Okumura, T.; Sato, S. Seasonal migration of sika deer in the Oku-Chichibu Mountains, central Japan. Mammal Study 2012, 37, 127-137. [CrossRef]

68. Enari, H.; Sakamaki, H. Landscape-scale evaluation of habitat uses by sympatric mammals foraging for bark and buds in a heavy snowfall area of northern Japan. Acta Theriol. (Warsz) 2012, 57, 173-183. [CrossRef] 
69. Sakuragi, M.; Igota, H.; Uno, H.; Kaji, K.; Kaneko, M.; Akamatsu, R.; Maekawa, K. Seasonal habitat selection of an expanding sika deer Cervus nippon population in eastern Hokkaido, Japan. Wildl. Biol. 2003, 9, 141-153. [CrossRef]

70. Ochiai, K. Capricornis crispus (Temminck, 1845). In The Wild Mammals of Japan; Ohdachi, S.D., Ishibashi, Y., Iwasa, M.A., Saitoh, T., Eds.; Shoukadoh: Kyoto, Japan, 2009; pp. 306-309.

71. Nagata, J. Cervus nippon Temminck, 1838. In The Wild Mammals of Japan; Ohdachi, S.D., Ishibashi, Y., Iwasa, M.A., Saitoh, T., Eds.; Shoukadoh: Kyoto, Japan, 2009; pp. 296-298.

72. Pianka, E.R. The structure of lizard communities. Annu. Rev. Ecol. Syst. 1973, 4, 53-74. [CrossRef]

73. Yasuda, M. Monitoring diversity and abundance of mammals with camera traps: A case study on Mount Tsukuba, central Japan. Mammal Study 2004, 29, 37-46. [CrossRef]

74. Matsuura, K. Bayesian Statistical Modeling Using Stan and R; Kyoritsu Shuppan: Tokyo, Japan, 2016; pp. 202-228. (In Japanese)

75. Montgomery, D.C.; Peck, E.A.; Vining, G.G. Introduction to Linear Regression Analysis, 5th ed.; Wiley: Hoboken, NJ, USA, 2013; pp. 372-388.

76. Gelman, A.; Carlin, J.B.; Stern, H.S.; Dunson, D.B.; Vehtari, A.; Rubin, D.B. Bayesian Data Analysis, 3rd ed.; CRC Press: New York, NY, USA, 2013; pp. 275-292.

77. Rowcliffe, J.M.; Kays, R.; Kranstauber, B.; Carbone, C.; Jansen, P.A. Quantifying levels of animal activity using camera trap data. Methods Ecol. Evol. 2014, 5, 1170-1179. [CrossRef]

78. Ridout, M.S.; Linkie, M. Estimating overlap of daily activity patterns from camera trap data. J. Agric. Biol. Environ. Stat. 2009, 14, 322-337. [CrossRef]

79. Pewsey, A.; Neuhäuser, M.; Ruxton, G.D. Circular Statistics in R; Oxford University Press: Oxford, UK, 2013 ; pp. 131-148.

80. Monterroso, P.; Alves, P.C.; Ferreras, P. Plasticity in circadian activity patterns of mesocarnivores in Southwestern Europe: Implications for species coexistence. Behav. Ecol. Sociobiol. 2014, 68, 1403-1417. [CrossRef]

81. Torretta, E.; Serafini, M.; Puopolo, F.; Schenone, L. Spatial and temporal adjustments allowing the coexistence among carnivores in Liguria (N-W Italy). Acta Ethol. 2016, 19, 123-132. [CrossRef]

82. Tsunoda, H.; Newman, C.; Peeva, S.; Raichev, E.; Buesching, C.D.; Kaneko, Y. Spatio-temporal partitioning facilitates mesocarnivore sympatry in the Stara Planina Mountains, Bulgaria. Zoology 2020, 141, 125801. [CrossRef] [PubMed]

83. R Core Team. R: A Language and Environment for Statistical Computing; R Foundation for Statistical Computing: Vienna, Austria, 2020.

84. Fox, J.; Weisberg, S. An R Companion to Applied Regression, 3rd ed.; Sage: Sauzend Oaks, CA, USA, 2019 ; pp. 385-436.

85. Fox, J.; Weisberg, S.; Price, B.; Adler, D.; Bates, D.; Baud-Bovy, G.; Bolker, B.; Ellison, S.; Firth, D.; Friendly, M.; et al. Package 'Car', Version 3.0-11. Available online: https://cran.r-project.org/web/packages/car/index.html (accessed on 12 October 2021).

86. Stan Development Team. Rstan: The R interface to Stan. R Package Version 2.21.2. Available online: http:/ / mc-stan.org (accessed on 12 October 2021).

87. Guo, J.; Gabry, J.; Goodrich, B.; Weber, S.; Lee, D.; Sakrejda, K.; Martin, M.; Sklyar, O.; Trustees of Columbia University; The R Core Team; et al. Package "rstan", Version 2.21.2. Available online: https://cran.r-project.org/web/packages/rstan/index.html (accessed on 12 October 2021).

88. Bürkner, P.-C.; Gabry, J.; Weber, S.; Johnson, A.; Modrak, M.; Badr, H.S.; Weber, F.; Ben-Shachar, M.S. Package “Brms”, Version 2.16.1. Available online: https://cran.r-project.org/web/packages/brms/index.html (accessed on 12 October 2021).

89. Bürkner, P.C. brms: An R package for Bayesian multilevel models using Stan. J. Stat. Softw. 2017, 80, 1-28. [CrossRef]

90. Rowcliffe, M. Package 'Activity', Version 1.3.1. Available online: https://cran.r-project.org/web/packages/activity/index.html (accessed on 12 October 2021).

91. Meredith, M.; Ridout, M. Package 'Overlap', Version 0.3.4. Available online: https://cran.r-project.org/web/packages/overlap/ index.html (accessed on 12 October 2021).

92. Lund, U.; Agostinelli, C. Package 'CircStats', Version 0.2-6. Available online: https://cran.r-project.org/web/packages/CircStats/ index.html (accessed on 12 October 2021).

93. Takahashi, S.; Higaside, D.; Fujita, M.; Yoneda, M. A preliminary study of the daily activity patterns of Sika deer (Cervus nippon) in the Kitakami mountains, Iwate prefecture, via infrared-triggered camera. Mamm. Sci. 2012, 52, 193-197, (In Japanese with English abstract). [CrossRef]

94. Tsukada, H. The utilization of grasslands by sika deer (Cervus nippon) and its feeding damage in grasslands. Jpn. J. Grassl. Sci. 2012, 58, 187-192. (In Japanese) [CrossRef]

95. Deguchi, Y.; Murayama, K. Habitat use and sex rate of sika deer in new distribution areas. Mamm. Sci. 2016, 56, 37-41, (In Japanese with English abstract). [CrossRef]

96. Kitagawa, Y.; Matsuyama, S.; Oota, K.; Okabe, Y.; Katsuyama, T.; Kishimoto, Y.; Sato, S.; Shibata, Y.; Nakagawa, T.; Nishioka, Y.; et al. Seasonal changes of time and space distribution, and daily activity pattern of yeso sika deer (Cervus nippon yesoensis) in eastern Hokkaido, Japan. Jpn. J. For. Environ. 2017, 59, 1-11, (In Japanese with English abstract). [CrossRef]

97. Borkowski, J. Flight behaviour and observability in human-disturbed sika deer. Acta Theriol. (Warsz) 2001, 46, 195-206. [CrossRef]

98. Liu, X.; Wu, P.; Songer, M.; Cai, Q.; He, X.; Zhu, Y.; Shao, X. Monitoring wildlife abundance and diversity with infra-red camera traps in Guanyinshan Nature Reserve of Shaanxi Province, China. Ecol. Indic. 2013, 33, 121-128. [CrossRef]

99. Chen, Y.; Xiao, Z.; Zhang, L.; Wang, X.; Li, M.; Xiang, Z. Activity rhythms of coexisting red serow and Chinese serow at Mt. Gaoligong as identified by camera traps. Animals 2019, 9, 1071. [CrossRef] 
100. Bhattacharya, T.; Bashir, T.; Poudyal, K.; Sathyakumar, S.; Saha, G.K. Distribution, Occupancy and activity patterns of goral (Nemorhaedus goral) and serow (Capricornis thar) in Khangchendzonga Biosphere Reserve, Sikkim, India. Mammal Study 2012, 37, 173-181. [CrossRef]

101. Ishida, K.; Yamane, A.; Akaiwa, T.; Igarashi, Y. Disribution of Japanese serow Capricornis crispus and sika deer Cervus nippon in Chichibu Mountains. Bull. Univ. Tokyo For. 1993, 89, 99-111, (In Japanese with English abstract).

102. Doko, T.; Chen, W. The geographical distribution and habitat use of the Japanese serow (Naemorhedus crispus) in the Fuji-Tanzawa region, Japan. J. Environ. Inf. Sci. 2013, 41, 53-62.

103. Takada, H. The summer spatial distribution of Japanese serows (Capricornis crispus) in an area without predation risk. Mamm. Biol. 2020, 100, 63-71. [CrossRef]

104. Terada, C.; Tatsuzawa, S.; Saitoh, T. Ecological correlates and determinants in the geographical variation of deer morphology. Oecologia 2012, 169, 981-994. [CrossRef] [PubMed]

105. Scott, K.M. Allometric trends and locomotor adaptations in the Bovidae. Bull. Am. Mus. Nat. Hist. 1985, 179, 197-288.

106. Geist, V. On the evolution of the Caprinae. In The Biology and Management of Capricornis and Related Mountain Antelopes; Soma, H., Ed.; Croom Helm: London, UK, 1987; pp. 3-40.

107. Takada, H.; Nakamura, K.; Minami, M. Effects of the physical and social environment on flight response and habitat use in a solitary ungulate, the Japanese serow (Capricornis crispus). Behav. Process. 2019, 158, 228-233. [CrossRef] [PubMed]

108. Sakuragi, M.; Igota, H.; Uno, H.; Kaji, K.; Kaneko, M.; Akamatsu, R.; Maekawa, K. Comparison of diurnal and 24hr sampling of habitat use by female sika deer. Mammal Study 2002, 27, 101-105. [CrossRef]

109. Kamei, T.; Takeda, K.I.; Izumiyama, S.; Ohshima, K. The effect of hunting on the behavior and habitat utilization of sika deer (Cervus nippon). Mammal Study 2010, 35, 235-241. [CrossRef]

110. Uzal, A.; Walls, S.; Stillman, R.A.; Diaz, A. Sika deer distribution and habitat selection: The influence of the availability and distribution of food, cover, and threats. Eur. J. Wildl. Res. 2013, 59, 563-572. [CrossRef]

111. Li, J.; Li, Y.K.; Liu, W.H. Autumn bed site selection by sika deer (Cervus nippon) in the Taohongling National Nature Reserve, China. Russ. J. Ecol. 2017, 48, 384-391. [CrossRef]

112. Najafi, J.; Farashi, A.; Zanoosi, A.P.; Yadreh, R. Water resource selection of large mammals for water resources planning. Eur. J. Wildl. Res. 2019, 65, 82. [CrossRef]

113. Bleich, V.C.; Marshal, J.P.; Andrew, N.G. Habitat use by a desert ungulate: Predicting effects of water availability on mountain sheep. J. Arid Environ. 2010, 74, 638-645. [CrossRef]

114. Shields, A.V.; Larsen, R.T.; Whiting, J.C. Summer watering patterns of mule deer in the Great Basin Desert, USA: Implications of differential use by individuals and the sexes for management of water resources. Sci. World J. 2012, 2012, 846218. [CrossRef] [PubMed]

115. Waddell, R.B.; O’Brien, C.S.; Rosenstock, S.S. Bighorn sheep use of a developed water in southwestern Arizona. Desert Bighorn Counc. Trans. 2007, 49, 8-17.

116. Chiba, H. The behaviour of Japanese serow, Capricornis crispus (TEMMINCK) in captivity: Part 1. Seasonal changes of behaviour in cage. J. Mammal. Soc. Jpn. 1966, 3, 8-14, (In Japanese with English abstract).

117. Hougen, T.; Ueda, Y.; Yamamoto, H. Survey on palatability by feeding of sika deer (Cervus nippon Temminck) in Arida area, Wakayama Prefecture. Bull. Wakayama Prefect. Exp. Station. Agric. For. Fish. 2017, 5, 61-71. (In Japanese)

118. Seki, Y. A Sika Deer Drinking Water of the River. Movie Arch. Anim. Behav. 2007. Available online: http://www.momo-p.com/ index-e.html (accessed on 27 November 2021). (In Japanese).

119. Yamada, Y. Japanese serow. In Field Survey Methods for Wildlife Management: From the Identification of Field Signs of Mammals to Data Analysis; Seki, Y., Enari, H., Kodera, Y., Tsuji, Y., Eds.; Kyoto University Press: Kyoto, Japan, 2015; pp. 59-68. (In Japanese)

120. Jiang, Z.-W. Sika deer. In Field Survey Methods for Wildife Management: From the Identification of Field Signs of Mammals to Data Analysis; Seki, Y., Enari, H., Kodera, Y., Tsuji, Y., Eds.; Kyoto University Press: Kyoto, Japan, 2015; pp. 39-52. (In Japanese)

121. Nowicki, P.; Koganezawa, M. Space as the potential limiting resource in the competition between the Japanese serow and the sika deer in Ashio, central Japan. Biosph. Conserv. 2002, 4, 69-77. [CrossRef]

122. Valeix, M.; Chamaillé-Jammes, S.; Fritz, H. Interference competition and temporal niche shifts: Elephants and herbivore communities at waterholes. Oecologia 2007, 153, 739-748. [CrossRef]

123. Fedriani, J.M.; Palomares, F.; Delibes, M. Niche relations among three sympatric Mediterranean carnivores. Oecologia 1999, 121, 138-148. [CrossRef]

124. Takeshita, T. Current situation and problems of miscaptured Japanese serows (Capricornis crispus) by snare traps in Komoro city, Nagano prefecture, Japan. Mamm. Sci. 2020, 60, 351-358. [CrossRef] 